Various forms of oral contraceptives have been available in France for several years because of their initial therapeutic role, but not everyone can afford them.

The family planning association called the Mouvement Français pour le Planning Familial (MFPF) has, however, been operating "underground" and has until recently got around the law by running the organization on the lines of a club with paying members. The organization now has a membership of 100,000 and has more than three hundred centres.

According to the new law, decisions about the manufacture and importation of contraceptives will be subject to a ruling by the public authority, and the sale of contraceptive products will be subject to an authorization of the Minister of Social Affairs. The sale of such articles will be confined to chemists' shops, while those oral contraceptives placed on the so-called "special list" will only be sold under prescription; and the doctors concerned will be required to consider the patients' medical history. Minors up to 18 years old under parental control requiring contraceptives, and similar young people up to 21 years old requiring oral contraceptives on the special list, will have to have a prescription as well as the written consent of a parent or legal guardian.

Under the new law, family planning associations will not be allowed to supply contraceptives as they have done in the past. Another blow to such organiza. tions is that all "antinatalist propaganda" will be forbidden, which means that people seeking advice from an association will have no means of finding it, either from advertisements, or, presumably, from telephone directories. The government intends to back up the law with fines and imprisonment for offenders.

Because the Social Security will not have to reimburse the costs of progesterones, as it does the cost of other medicines, some doctors contend that it is the poor who will suffer most. There is also a feeling that the law places too much responsibility on the doctors, allowing them to interpret it according to their moral and religious principles. Others feel that it is intolerable that patients should be so closely controlled in so personal a matter. One objector on medical grounds, Professor Jacques Huguier, has suggested that, if the law is not repealed before it comes into action on March 1, wholesale resignation of the medical profession might be called for. An extremist's view, perhaps, but it is evidence of the kind of opposition the law is meeting.

\section{More European Physics}

The plan for forming a European Physical Society has been modified somewhat in the light of the discussions of the steering committee which met on January 30 at the Battelle Institute in Geneva. For one thing, it has bcen decided to postpone the large conference which had first been hoped to inaugurate the society at Florence in September this year. This event will not now take place until 1969. Instead there will be an inaugural ceremony in Geneva in September this year. At the same time it appears that serious discussions have been opened with a number of countries from Eastern Europe-Yugoslavia, Czechoslovakia, Hungary and Rumania. Although the representatives of the physical societies in these countries have been given clearly to understand that the formation of a European Physical Society will not be obliged to allow them to determine their own relationship to it, there does now seem hope that they will eventually be associated with the work at some stage. In the meantime, it appears that there have emerged a number of difficulties about the financial provisions in the constitution although these will most probably be resolved at the next meeting of the steering committee due to be held in the spring this year. With luck this will be held in Prague, but otherwise in Vienna.

It has been agreed that the headquarters of the society will be in Geneva at the physics department of the university, 32 Boulevard d'Yvoy, 1211 Geneva 4. It has also been agreed that the working language of the society will be English. At the meeting on January 30 it was agreed that the European Chemical Society should publish a bulletin, principally to keep European physicists informed about the discussions now going on, but there seems some confusion about the way in which this will be accomplished. In the circumstances, it is not surprising that the steering committee has not yet had a chance to take up the more complicated question of how to organize the learned journals in physics which cater for European scientists. The first inclination seems to be to divide physics as a whole into fields which could be parcelled out to the journals which already publish original articles in physics, and in this spirit existing publishers are likely to be approached in the next two weeks. It would not, however, be surprising if in the end the European Physical Society decided to follow a more informal and more empirical course, if only for the sake of the flexibility it would thereby gain.

\section{New Hope for Planning}

THE first rumblings of a new assault on national planning were heard last week when Mr Peter Shore, Secretary of State for Economic Affairs, presented a Government paper to a meeting of the National Economic Development Council. It appears that few details were given at the meeting, but it was stated that another paper would be presented after the budget on March 17, with broad outlines of the way the economy should develop. The economic development councils for the different sectors of industry will then be able to discuss the projections and work out what the effects will be on their own sections of industry. There are twenty-one councils, known affec-

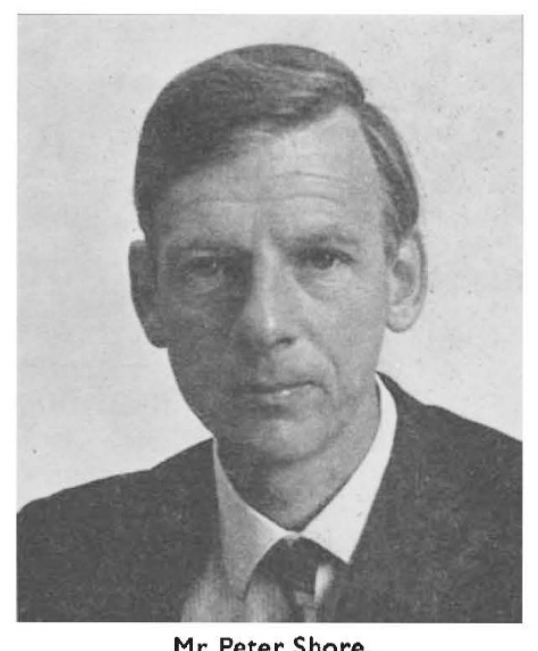

Mr Peter Shore. 
tionately and sometimes derisively as little Neddies, covering about two-thirds of private industry, with representatives from management and unions. When the results of their deliberations are known the Government will add them to results from its own studies and produce a more detailed planning document in the autumn. It is acknowledged that prices and incomes will be important considerations in any plan of this kind. The whole subject of national planning has been regarded rather sceptically since the National Plan was abandoned in July 1966, but it is thought that the present state of the economy calls for another attempt, provided that it is more flexible than the last.

\section{New Look for Heathrow}

The British Airports Authority, which runs commercial airfields in Britain, last week unveiled plans for the development of Heathrow, London's major airport. With the advent of the Bocing 747 , which will be arriving on commercial flights to London by the summer of 1970 , development of Heathrow to handle the increase in passengers has become urgent. Although the new plan is to cost $£ 10$ million, it represents a face-lift for only a small part of the airport.

The new section of the airport will be a T-shaped pier, with an upright $900 \mathrm{ft}$. long and a crosspiece $1,000 \mathrm{ft}$. long. The aireraft stands will be positioned along the crosspiece, seven each side, and passengers will be carried along the upright section on a travelling pavement. For those who prefer to make the journey on foot, ample space will be provided on either side of the conveyor. Telescopic air jetties will link the aircraft with waiting rooms. There will also be changes in the terminal buildings; a new passenger terminal building, prosaically called Terminal 1, will be built, and the existing Europa and Britannic buildings will be merged and called Terminal 2 . The Oceanic building will be renamed Terminal 3 , and a new arrivals terminal will also be built. By the time the 747 service across the Atlantic is in full swing, it will be necessary to separate arriving and departing passengers into two separate terminals. Thus by 1970 , Terminal 3 (the Oceanic building to today's travellers) will be devoted to departing passengers, while the new arrival terminal looks after those coming into Britain. By this time, the authority says, the number of departing and arriving passengers on long haul services is likely to reach 2,700 an hour in each direction.

The main difficulty will arise when several $747 \mathrm{~s}$ arrive at once, or within a few minutes of each other. Each will be carrying up to 490 passengers. Unless the capacity of the airport bus services is to be severely overstretched, a rail link between central London and the airport must be built.

\section{Marine Science on Record}

THE first comprehensive directory of marine science in the United Kingdom has just been published. (The Royal Society, $£ 2$ ). It has been prepared on behalf of the Royal Society's British National Committee for Occanographic Research with the co-operation of the Natural Environment Research Council, and it should prove to be of great help to everyone working in this rapidly growing subject.

For the most part, the book consists of the names of scientists listed by establishment and arranged in four sections. Sections 1 and 2 include the marine science laboratories, both government and university, with details of the scientists employed in them and of the laboratories themselves. Information given under each institution includes facilities for visiting research workers, training courses, and a selected bibliography of research done there. There are as many as 57 university departments in the United Kingdom which have continuing interests in marine science.

Sections 3 and 4 cover university departments and government-supported laboratories in which marine science has only a minor role-but where there are staff working on some aspect of the subject. A further 42 academic and 13 government-supported departments are listed in these sections.

There is often confusion over the organization of research in interdisciplinary fields such as oceanography. It is helpful, therefore, that the directory includes a summary of the overall organization of oceanographic and fisheries research in the United Kingdom and the part played by the national programme in international activities.

The research ships available to British scientists and the libraries offering facilities to them are listed in two appendices.

\section{Scientist on the Move}

Mr B. T. PRICE, at present director of the Defence Operational Analysis Establishment of the Ministry of Defence at Byfleet in Surrey, is to become Chief Scientific Adviser at the Ministry of Transport on April 1. Mr Price has worked in turn for the Atomic Energy Authority and for the scientific group at the headquarters of the Ministry of Defence. He has been largoly responsible for setting up the Byfleet establishment in the past few years. He is a physicist by trade.

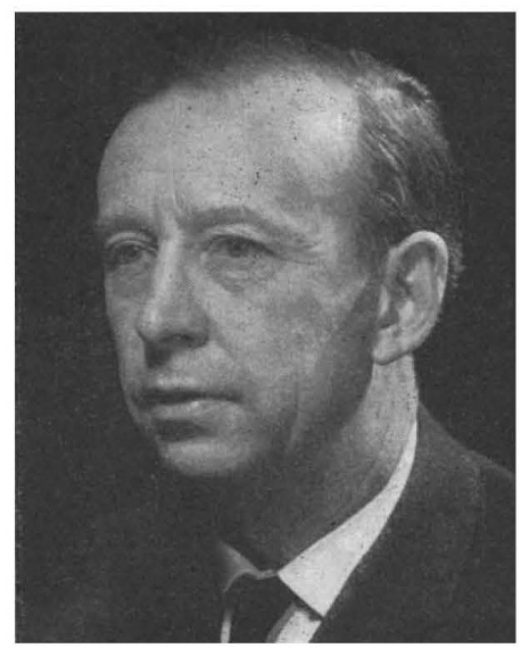

Mr B. T. Price.

This new appointment comes at a time when it seems that the Ministry of Transport would like to see more of what the British Government spends on rcsearch and development devoted to the art of moving about.

\section{Make or Break}

DURINa the past year or so, the Electrical Research Association has done its share of breast-beating in 